\title{
THE STUDY OF TRAVEL SATISFACTION IN MRT JAKARTA DURING THE PANDEMIC OF COVID-19
}

\author{
Ronald SUKWADI* \\ Atma Jaya Catholic University of Indonesia, Department of Industrial Engineering, Indonesia, e-mail: ronald.sukwadi@atmajaya.ac.id \\ Samantha CORY \\ Atma Jaya Catholic University of Indonesia, Department of Industrial Engineering, Indonesia, e-mail: corycornelia.sc@gmail.com \\ Yun-Chia LIANG \\ Yuan Ze University, Department of Industrial Engineering and Management, Taiwan ROC, e-mail: ycliang@ saturn.yzu.edu.tw
}

\begin{abstract}
Citation: Sukwadi, R., Cory, S., \& Liang, Y.C. (2022). THE STUDY OF TRAVEL SATISFACTION IN MRT JAKARTA DURING THE PANDEMIC OF COVID-19. GeoJournal of Tourism and Geosites, 40(1), $191-199$. https://doi.org/10.30892/gtg.40123-819
\end{abstract}

\begin{abstract}
The aims of the present study are as follows: a) to explore the factors which are imperative to measure the service quality of the MRT Jakarta; b) to construct a detailed satisfaction model to measure the effects of service quality and the perceived accessibility as mediating variable on overall satisfaction with travel of MRT Jakarta. The 24 variables were tested with SEM method using R Studio. It is applied to define a causal model between each of variables. Furthermore, to evaluate the qualitative data, the thematic analysis is also applied. Based on the study results, the satisfaction with travel would increase if perceived accessibility is increasing by service quality. The increase of perceived accessibility will make the users more accessible and easier to live their lives, leading to satisfaction with travel. The qualitative data processed with them atic analysis showed the most frequency quality concerned in MRT Jakarta is SS1 (Presence of Guard) and SS2 (Risk of Interference with Other Passengers). The service quality affects perceived accessibility and travel satisfaction. Likewise, perceived accessibility affects travel satisfaction. Also, it is supported by the thematic analysis from qualitative data, which compared by passengers' input about MRT Jakarta in COVID-19 Pandemic.
\end{abstract}

Key words: service quality, MRT Jakarta, travel satisfaction, perceived accessibility, pandemic of COVID-19

\section{INTRODUCTION}

As the capital city of Indonesia and one of many other big cities in Indonesia, Jakarta is increasing rapidly in every dimension of the economy's wheels. With the growth of the population, the need for transportation will increase. Unfortunately, it has resulted in congestion in many Jakarta areas. According to TomTom Traffic Index, Jakarta has become the tenth city of many other cities with the most traffic globally, with 53\% of the average congestion level. The growth of the urban transport trend in Jakarta was affected by many factors, including population, geographical de-concentration, increases in income, motorized transport availability, and increases in other activities (Santosa and Basuki 2003).

As the capital city of a developing country, Jakarta must provide ideal infrastructure services in many ways. Hence, to support its high mobility and traffic for modernization, the Government has responded by establishing a modern subway system known as Mass Rapid Transit (MRT). It is the outcome of the policy of the Government of Jakarta in Governor Regulation 103 of 2007. According to Effendi on jakarta.bisnis.com, MRT takes place as a service to provide the city mobilization with accessibility and connectivity towards inclusive public transportation development.

MRT in Jakarta has been operated since March $24^{\text {th }}, 2019$. This system convinced the public to solve the high traffic jam or congestion and is an ideal transportation system in a big city. The first phase of MRT connects Lebak Bulus and Bundaran HI for 13 stations divided into elevated sections and underground. Besides that, MRT also connects with other public transportation such as KRL Commuter Line and Transjakarta. The new modern transportation mode in Jakarta, MRT, is required to provide the services for the community to meet their need for mobilization (Purnomo and Mufhidin, 2020). MRT train in Jakarta was named Ratangga, and it has 16 Ratangga series. The time record for the journey from Lebak Bulus station to Bundaran HI station is 30 minutes. In a normal situation, MRT Jakarta operates from 05.00 a.m. until 00.00 a.m. every day. Today, it has just the first phase. The second phase will be released soon (www.jakartamrt.co.id).

At the beginning of 2020, the world experienced a global pandemic outbreak of infectious diseases. It is called COVID19. The government of Indonesia has never applied lockdowns during the COVID-19 transmission. The Indonesian government argues that the best approach during the COVID-19 flow is to balance between economic and the pandemic control. In doing so, the government has never imposed national lockdowns since the first confirmed cases on March 2nd, 2020 (van Empel et al., 2020). After the government announced that two female Indonesians were positively infected by

\footnotetext{
* Corresponding author
} 
the coronavirus, the government has proposed the partial lockdowns or the large social restriction, so-called "Pembatasan Sosial Berskala Besar" (PSBB), to hamper the COVID-19 transmission (Khairulbahri, 2021).

The pandemic has increased the need for greater understanding and integration of governance, technology and citizen behavior (Shaw et al., 2020), providing additional lessons and case materials for the building of resilience into transportation systems (Kim et al., 2018). Regular use of public transportation might be a risk for acquiring symptomatic COVID-19 (Steinwender et al., 2021). The COVID-19 pandemic brought unprecedented levels of disruption to the local and regional transportation networks throughout Indonesia, especially the capital city-Jakarta (Yao et al., 2021). Hence, in April 2020, the Government of Indonesia decided to undertake large-scale social distancing in several big cities in Indonesia, in response to this pandemic. Consequently, of its decision, the usage of public transportation, especially MRT, has immensely decreased. Many companies closed and forbade employees from coming to work and let the employees work from their homes. Figure 1 and 2 shows the implementation's effect of large-scaling social distancing in April 2020 in Jakarta and the current development (2021). The average number of MRT passengers per day in April only reached 4,059 passengers, and it decreased by around $90 \%$ from the past month. However, the graphic (Figure 1) tends to go up from June 2020 until July 2020, although not like the two months early. The decrease of MRT passengers is a result of the Government's policy to do large-scale social distancing. The decision affects using MRT and decreasing passengers.

This global pandemic affects passengers to comply with existing health protocols such as wearing a mask, keeping a safe distance, always bring personal hand sanitizer, should not sneezing carelessly, etc. This matters in every station on MRT to provide strict regulations to all customers when entering the station. To keep passengers feel safe and secure, the company must provide their best quality of services. According to Yuniarti and Aditya (2020), following the health protocol rules at MRT Jakarta, passengers are expected to bring 12 items, including masks, multi-trip roaming cards, MRTJ mobile apps, hand sanitizers, personal worship tools, personal drinking bottles, vitamins (if needed), dry wipes, wet wipes, disinfectant, and personal cutlery. In addition, people entering the Jakarta MRT region must follow the regulations for verifying the maximum temperature of 37.3 degrees Celsius, and there is platform marking stickers that the community must respect. As a result, the principles of social distancing can be effective. MRT Jakarta also performs intensive cleaning of each train, both inside and outside, employing disinfectants, health and hygiene officers, personal protective equipment, and temperature checks for passengers at the entry to the 62-67 per train restriction.

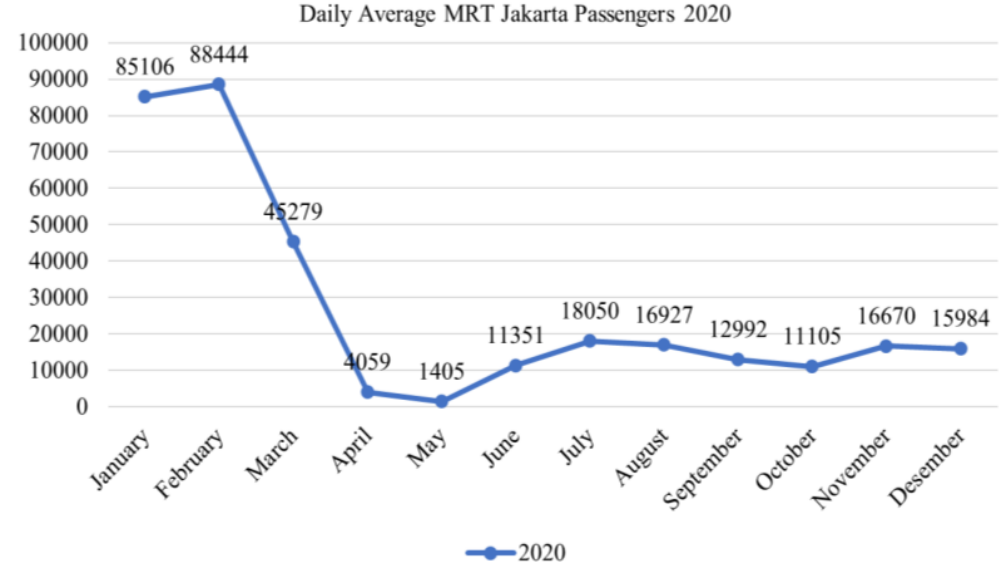

Figure 1. Data of the average MRT passenger per day in 2020 (number of passengers) (Source: https://jakartamrt.co.id/)

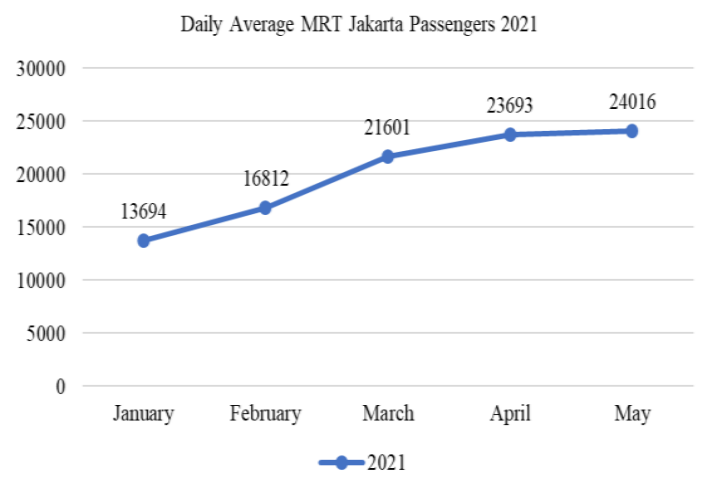

Figure 2. Data of the average MRT passenger per day in 2021 (number of passengers) (Source: https://jakartamrt.co.id/)

Nevertheless, the quality for serving the needs of the passengers must keep running. Excellence service quality plays a vital role and have become a top priority for the company to achieve their goals and gain competitive advantages (Sukwadi, 2015a). The impact of the service experience on consumers' satisfaction is important for service providers. Service providers must provide customers with delightful service experience to attract more passengers and achieve higher customer satisfaction (Sukwadi et al., 2012; Sukwadi, 2015b). The vision of MRT Jakarta is to become a leading public transportation service provider committed to driving economic growth through increased mobility, reduction of congestion, and development of urban transit systems (www.jakartamrt.co.id). As for its vision, Lättman et al. (2016a) stated that reliable measures of perceived accessibility are needed to the following up on goals and vision. Perceived accessibility has been defined as "the ease of living a satisfying life" for using the transport system. Perceived accessibility includes the individual perspective with demographic characteristics and also pointed to an important goal emphasizing service quality (Dong et al., 2006; Cheng and Chen, 2015; Lättman et al., 2016b) . Perceived accessibility varies on income, wheelchair user, mobility impairments caused by aging and transit dependent (Márquez et al., 2019).

The demand for satisfying services is more challenging in this pandemic. However, service quality becomes the key determination and perceptions of accessibility (Friman et al., 2020). With this pandemic situation, is the community able to live their lives as they want to? Where do people feel it is easy to travel today? Are people able to do their activities like before using the MRT service? Are people satisfied with how they travel today? The perceived accessibility was first developed by Lättman et al. (2016b). They developed the scale of perceived accessibility that aims to focus on the perceived possibility for society to use public transport. Besides that, perceived accessibility also targets the ease of 
engaging in preferred activities by using public transport. The perceived accessibility scale can be used to determine the best needed according to each individual. Therefore, it can improve the accessibility of public transport.

Lättman et al. (2016b), in their research, discussed the findings that quality is an essential factor for perceived accessibility. This finding leads the user to perceive public transport to be more accessible. The public transport quality dimension that is more critical on perceived accessibility includes reliability and information. These findings aim at the building of a sustainable transport system for public users. According to Parasuraman et al. $(1985,1988)$, the perception and evaluations of the customer to the provided services affect the service quality of its company.

Other researchers discussed that information and comfort are important transport qualities for better-perceived accessibility (Friman et al., 2020). They suggested the cost dimension could be considered in future studies while the cost dimension also an important factor for better-perceived accessibility. Perceived accessibility was used to see the differences between people's groups, such as age, gender, income rate, etc. The findings of Lättman et al. (2019) described and hypothesized that travel satisfaction is affected by perceived accessibility. In the transportation context, many studies and researches have been conducted (Haron et al., 2015, 2016; Nguyen Van et al., 2018; Sze-Siong and Aksan, 2018; Monmousseau et al., 2020), customer satisfaction was used to measure the performance of transportation system through the perception of its quality. In this research, perceived accessibility will be the mediating variable that help to verify the indirect effect between service quality and travel satisfaction. Structural Equation Modeling (SEM) is viewed as one a general statistical modeling technique that is commonly used as a modeling approach that integrates regression analysis and factor analysis (Davvetas et al., 2020; Hox and Bechger, 2015).

Besides testing the hypothesis by the Structural Equation Model (SEM), the researcher wants to know the frequently mentioned indicators from passengers' opinions using the thematic analysis. This analysis is used to identify, an alyze, and find the code from qualitative data (Salleh et al., 2017; Heriyanto, 2018; Mellado et al., 2020). Also, the researcher wants to compare the satisfaction for using MRT Jakarta influenced by perceived accessibility and service quality during COVID-19 pandemic between the captive users and choice users. The captive users are defined as the user that only has one transport option. In comparison, the choice users are defined as the user with many other options of transport (Zhao et al., 2014; De Oña et al., 2015). The differences between the captive and choice users can be seen by how they would feel about accessibility and satisfaction if they travel with MRT Jakarta.

The aims of the present study are as follows: a) to explore the factors which are imperative to measure the service quality of the MRT Jakarta; b) to construct a detailed satisfaction model to measure the effects of service quality and the perceived accessibility as mediating variable on overall satisfaction with travel of MRT Jakarta. This research can be used to determine, evaluate, and develop the service quality for the perceived accessibility and passenger's satisfaction in MRT Jakarta, especially during and post of the Covid-19 pandemic. The present study's findings provide decision-makers with necessary information regarding the rapid mass transit in Jakarta to deliver better public services.

In order to achieve these objectives, the paper will proceed as follows: immediately, in methodology section, the model development and statistical method i.e., Structural Equation Modelling is described; after this, questionnaire survey design and data collection are also presented in this section; while in the result section, results of descriptive analysis, exploratory factor analysis, confirmatory factor analysis, and thematic analysis are presented whereas discussion of the results is shown in next section; lastly, conclusions and future research are discussed in the last section.

\section{MATERIALS AND METHODS}

\section{Model development and hypothesis}

The present study focused on the service quality, perceived accessibility, and travel satisfaction in MRT Jakarta during the pandemic of COVID-19 in second order model. Higher-order model shows the connection between second-order latent variable with the indicators in first-order latent variable (Koufteros et al., 2009; Laili and Otok, 2014). Service provided by the transport system should fulfill travel needs to reach satisfaction with travel. It is believed that improving service quality can help achieve passengers' satisfaction with travel (Shah et al., 2020; Soltanpour et al., 2020; Haron et al., 2015, 2016; Nguyen Van et al., 2018; Sze-Siong and Aksan, 2018; Monmousseau et al., 2020). Lai and Chen (2011) reported that the more positive customer expectation of highservice quality service, the more satisfaction was obtained.

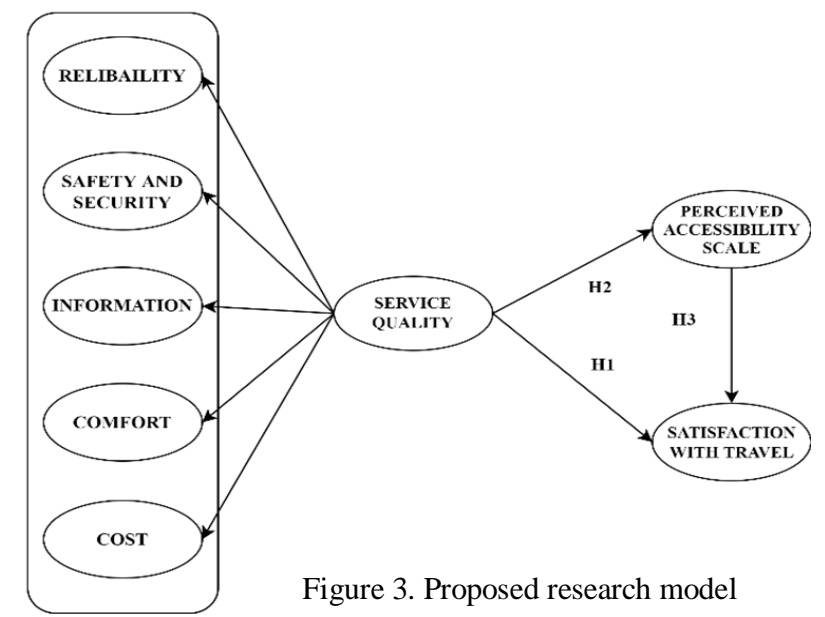

Thus, service quality appears to be positively related and essential to perceived accessibility. The service quality dimensions used are reliability, safety, security, information, comfort, and cost. A previous study highlighted that service quality has been important for perceived accessibility in daily travel (Lättman et al., 2016b; Friman et al., 2020). Perceived accessibility has a role in travel satisfaction and general life satisfaction (Lättman et al., 2019; Inturri et al., 2021). It became the mediating role between service quality and satisfaction with travel. The higher the satisfaction with travel that customer feels, the higher perceived accessibility and quality are given. The service quality also has a role in drive customer satisfaction (Lai and Chen, 2011; Hussein and Hapsari, 2014; Chauhan et al., 2021). Therefore, hypotheses conducted in this research are (Figure 3): 
H1: Service quality has an effect on satisfaction with travel

H2: Service quality has en effect on the perceived accessibility scale

H3: Perceived accessibility scale as a mediating variable has an effect on satisfaction with travel

Table 1. Definition of the operational variables

\begin{tabular}{|c|c|c|c|}
\hline Variable & Definition & Indicator & $\begin{array}{r}\text { Reference } \\
\end{array}$ \\
\hline \multirow{5}{*}{$\begin{array}{l}\text { Reliability } \\
\text { (RE) }\end{array}$} & \multirow{5}{*}{$\begin{array}{l}\text { Reliability is the overall } \\
\text { competencies to provide the } \\
\text { service dependently. It also } \\
\text { means the accuracy of the } \\
\text { services (Henderson, 2013) }\end{array}$} & Travel times on MRT are reasonable & (Friman et al., 2020) \\
\hline & & MRT mostly runs on schedule & (Friman et al., 2020) \\
\hline & & I am satisfied with the number of departures & (Friman et al.,2020) \\
\hline & & Ease to changeover to other modes (transfer) from MRT & (Mandhani et al., 2020; Friman et al., 2020) \\
\hline & & Payment method is easy & $\begin{array}{l}\text { (Lättman et al., 2016a; Mandhani et al., } \\
\text { 2020) }\end{array}$ \\
\hline \multirow{3}{*}{$\begin{array}{l}\text { Safety \& } \\
\text { Security } \\
\quad(\mathrm{SS})\end{array}$} & \multirow{3}{*}{$\begin{array}{l}\text { Safety \& Security is } \\
\text { protection to the passenger } \\
\text { to prevent disturbance, } \\
\text { accident risk, and criminal } \\
\text { danger. (Haron et al., 2015) }\end{array}$} & Presence of police and security guard & (Haron et al., 2015; Haron et al., 2016) \\
\hline & & Risk of interference from other passengers & (Haron et al., 2015; Haron et al., 2016) \\
\hline & & Personal safety & (Haron et al., 2015; Haron et al., 2016) \\
\hline \multirow{3}{*}{$\begin{array}{l}\text { Information } \\
\quad(\mathrm{IF})\end{array}$} & \multirow{3}{*}{$\begin{array}{l}\text { The information available } \\
\text { for the travel } \\
\text { (Lättman et al., 2016) }\end{array}$} & $\begin{array}{l}\text { The information provided is good when traffic problems } \\
\text { occur }\end{array}$ & (Friman et al., 2020) \\
\hline & & The information provided is good at stops and terminals & (Lättman et al., 2016a; Friman et al., 2020) \\
\hline & & $\begin{array}{l}\text { The information provided is good on any other } \\
\text { communication technologies }\end{array}$ & $\begin{array}{l}\text { (Lättman et al., 2016a; Mandhani et al., } \\
\text { 2020) }\end{array}$ \\
\hline \multirow{4}{*}{$\begin{array}{l}\text { Comfort } \\
\text { (CF) }\end{array}$} & \multirow{4}{*}{$\begin{array}{l}\text { How comfortable access to } \\
\text { the service } \\
\text { (Redman et al., 2013) }\end{array}$} & Traveling by MRT is comfortable & (Friman et al., 2020) \\
\hline & & ly get a seat when I tric & \begin{tabular}{|l|} 
(Friman et al., 2020) \\
\end{tabular} \\
\hline & & T Station & (De Oña et al., 2015 \& Friman et al., 2020) \\
\hline & & ence at MRT & (Friman et al., 2020 \& Mandhani et al., 2020) \\
\hline \multirow{2}{*}{$\begin{array}{l}\text { Cost } \\
(\mathrm{CS})\end{array}$} & \multirow{2}{*}{$\begin{array}{l}\text { The monetary cost of the } \\
\text { service (Redman et al., } \\
\text { 2013) }\end{array}$} & Public transport gives value for money & (Friman et al., 2020) \\
\hline & & Public transport fares are reasonable & (Friman et al., 2020) \\
\hline \multirow{4}{*}{$\begin{array}{l}\text { Perceived } \\
\text { Accessi- } \\
\text { bility } \\
\text { Scale } \\
\text { (PAC) }\end{array}$} & \multirow{4}{*}{$\begin{array}{l}\text { A way to use the } \\
\text { transport system for a } \\
\text { satisfactory living } \\
\text { (Lättman et al., 2016a) }\end{array}$} & $\begin{array}{l}\text { Considering how I travel today it is easy to do my } \\
\text { daily activities with MRT }\end{array}$ & $\begin{array}{l}\text { (Lättman et al., 2016a; Lättman et al., } \\
\text { 2016b) }\end{array}$ \\
\hline & & $\begin{array}{l}\text { Considering if MRT was the only mode of travel, I } \\
\text { would able to live my life as I want to }\end{array}$ & $\begin{array}{l}\text { (Lättman et al., 2016a, Lättman et al., } \\
\text { 2016b) }\end{array}$ \\
\hline & & $\begin{array}{l}\text { Considering how I travel today I can do all } \\
\text { activities I prefer with MRT }\end{array}$ & $\begin{array}{l}\text { (Lättman et al., 2016a; Lättman et al., } \\
\text { 2016b) }\end{array}$ \\
\hline & & $\begin{array}{l}\text { Access to my preferred activities is satisfying } \\
\text { considering how I travel today with MRT }\end{array}$ & $\begin{array}{l}\text { (Lättman et al., 2016a; Lättman et al., } \\
\text { 2016b) }\end{array}$ \\
\hline \multirow{3}{*}{$\begin{array}{l}\text { Satisfaction } \\
\text { with } \\
\text { Travel } \\
\text { (TS) }\end{array}$} & \multirow{3}{*}{$\begin{array}{l}\text { Satisfaction with travel is } \\
\text { the response of the } \\
\text { customer about } \\
\text { expectation and } \\
\text { experience (Woodruff, } \\
\text { 1997; Lättman et al., 2019) }\end{array}$} & Cognitive Quality Evaluation & $\begin{array}{l}\text { (Chomeya, 2010; Hsu and Liao, 2019; } \\
\text { Lättman et al., 2019) }\end{array}$ \\
\hline & & $\begin{array}{l}\text { Affective Evaluation of Feelings of Boredom vs. } \\
\text { Enthusiasm }\end{array}$ & $\begin{array}{l}\text { (Chomeya, 2010; Hsu and Liao, 2019; } \\
\text { Lättman et al., 2019) }\end{array}$ \\
\hline & & $\begin{array}{l}\text { Affective Evaluation of Feelings of Stress vs. } \\
\text { Relaxation }\end{array}$ & $\begin{array}{l}\text { (Chomeya 2010; Hsu and Liao 2019; } \\
\text { Lättman et al., 2019) }\end{array}$ \\
\hline
\end{tabular}

\section{Research design}

This research will use quantitative data from the data survey gathered by distributing the questionnaire from May until July 2021. The questionnaire used and presented to the respondent consists of 2 parts, demographic data and 24 questions based on the model indicators. This research used the multiple-choice type with a Likert scale from 1 to 7 . According to Lewis (1993), the Likert scale of 7 points has a stronger correlation result. The seven-points Likert scale tends to be easier to use, more accurate, and better reflect the respondent. Moreover, this Likert scale is the best solution for questionnaires to conclude the usability evaluations (e.g., satisfaction survey) (Finstad, 2010). Besides Likert-type questions, the researcher also used open questions for opinions about MRT Jakarta's quality during the pandemic of COVID-19. The sampling technique in this research is non-probability sampling. This technique is not randomized methods. With this type of sampling, the participant was targeted and chose by the researcher in track of the purpose in the research. People from specified group was selected and sought out to represent the research purposes (Showkat and Parveen, 2017). Based on Bartlett et al. (2001) for determining appropriate sample size in survey research, there is a formula called Cochran formula as below:

$$
n_{0}=\frac{(t)^{2} \times(s)^{2}}{(d)^{2}} \quad \begin{array}{lll}
\mathrm{n}_{\mathrm{o}} & =\text { sample size } \\
\mathrm{t} & =\text { level of risk (alpha level of } 0.05 \text { is } 1.96) \\
\mathrm{s} & =\text { estimate standard deviation ((range of scale)/(number of standar deviation) }) \\
\mathrm{d} & =\text { acceptable margin of error (number of point scale } \times \text { margin error) }
\end{array}
$$

Hence, the minimum number of respondents for this research is calculated with the Cochran formula below (Bartlett et al., 2001):

$$
n_{0}=\frac{(1.96)^{2} \times\left(\frac{7}{6}\right)^{2}}{(7 \times 0.03)^{2}}=118,567=119
$$

According to Sreejesh et al. (2014), there are rules of thumb for determining the sample size. For sample size, at least five times of the indicators entered into the questionnaire. This research has 24 indicators to ask the respondents. Thus, the 
minimum number of respondents for this research would be 120 samples. The minimum number of respondents with the Cochran formula by Bartlett et al. (2001) is 119 respondents, while the minimum number of respondents with a rule of thumb by Sreejesh et al. (2014) is 120 respondents. In conclusion, the minimum sample size for this research is 120 respondents. The sample in this research was passengers in MRT Jakarta during the pandemic of COVID-19. Respondents in this research were 264 people. At the beginning, data should be processed through the validity and reliability tests using R Studio. This test aims to find out that the model's instrument is reliable and has a valid output. If the measurement model is not valid, the instrument should be refined and defined in the new study. In case it is valid, then the model continues to the next stage. The processes of the SEM method will be tested by using the R studio. Besides the SEM method for quantitative data, this study also employs thematic analysis to identify the most frequent service quality indicator from the qualitative data.

\section{RESULTS AND DISCUSSION}

\section{Profile of respondents}

Based on data obtained from 264 respondents, the majority of respondents were female $(59.8 \%)$, the majority were 21-25 years old $(50.75 \%)$, the majority lived in West Jakarta (21.96\%), the majority worked (43.94\%), the majority had range Rp1.000.000 - Rp5.000.000 in monthly salary (27.65\%), the station majority was Bundaran HI station (28.4\%). In addition, the majority were choice users $(91.67 \%)$.

\section{Exploratory factor analysis}

Data were tested by validity using Rstudio. There is a function in Rstudio called "cor.test". The Pearson (r) correlation measurement was used. This measurement is the most frequently used of many multivariate calculations. Values affect the coefficient, making the relationship stronger and normally distributed (Mukaka, 2012). After the validity test, the data will go through a reliability test used to measure the indicators of a latent construct to show how the indicators are interrelated. When it gives high reliability, it means a better relationship between a construct and indicators. According to Hair et al. (2009) the rating scale is the Cronbach's Alpha score.

Table 2 provides the final validity and reliability test result using R studio with 264 data of respondents which are the passengers of MRT Jakarta during the pandemic of COVID-19. The reliability of the samples was identified by using the overall Cronbach's alpha (0.6-0.9) and found to be quite good (Hair et al., 2009).

Table 2. Results of explaratory factor analysis

\begin{tabular}{|c|c|c|c|}
\hline Number & Items & Pearson Correlation & Cronbach's Alpha \\
\hline 1 & Reliability & & 0.600 \\
\hline RE1 & Travel times on MRT are reasonable & 0.716 & \\
\hline RE2 & MRT mostly runs on schedule & 0.657 & \\
\hline RE3 & I am satisfied with the number of departures & 0.599 & \\
\hline RE4 & Ease to changeover to other modes (transfer) from MRT & 0.549 & \\
\hline RE5 & Payment method is easy & 0.624 & \\
\hline 2 & Safety and Security & & 0.753 \\
\hline SS1 & Presence of police and security guard & 0.757 & \\
\hline SS2 & Risk of interference from other passengers & 0.890 & \\
\hline SS3 & Personal safety & 0.806 & \\
\hline 3 & Information & & 0.774 \\
\hline IF1 & The information provided is good when traffic problems occur & 0.833 & \\
\hline IF2 & The information provided is good at stops and terminals & 0.861 & \\
\hline IF3 & The information provided is good on any other communication technologies & 0.798 & \\
\hline 4 & Comfort & & 0.730 \\
\hline CF1 & Traveling by MRT is comfortable & 0.691 & \\
\hline CF2 & I normally get a seat when I travel with MRT & 0.582 & \\
\hline CF4 & Convenience at MRT & 0.548 & \\
\hline 5 & Cost & & 0.609 \\
\hline CS1 & Public transport gives value for money & 0.817 & \\
\hline CS2 & Public transport fares are reasonable & 0.881 & \\
\hline 6 & Perceived Accessibility & & 0.900 \\
\hline PAC1 & Considering how I travel today it is easy to do my daily activities with MRT & 0.790 & \\
\hline PAC2 & Considering if MRT was the only mode of travel, I would able to live my life as I want to & 0.892 & \\
\hline PAC3 & Considering how I travel today I can do all activities I prefer with MRT & 0.917 & \\
\hline PAC4 & Access to my preferred activities is satisfying considering how I travel today with MRT & 0.913 & \\
\hline 7 & Satisfaction with Travel & & $\mathbf{0 . 7 8 8}$ \\
\hline TS1 & Cognitive Quality Evaluation & 0.841 & \\
\hline TS2 & Affective Evaluation of Feelings of Boredom vs. Enthusiasm & 0.839 & \\
\hline TS3 & Affective Evaluation of Feelings of Stress vs. Relaxation & 0.843 & \\
\hline
\end{tabular}

\section{Structural Equation Model result}

This study used a structural equation model (SEM), and was tested with R studio. The result was the appropriate model as shown in the Figure 4. 


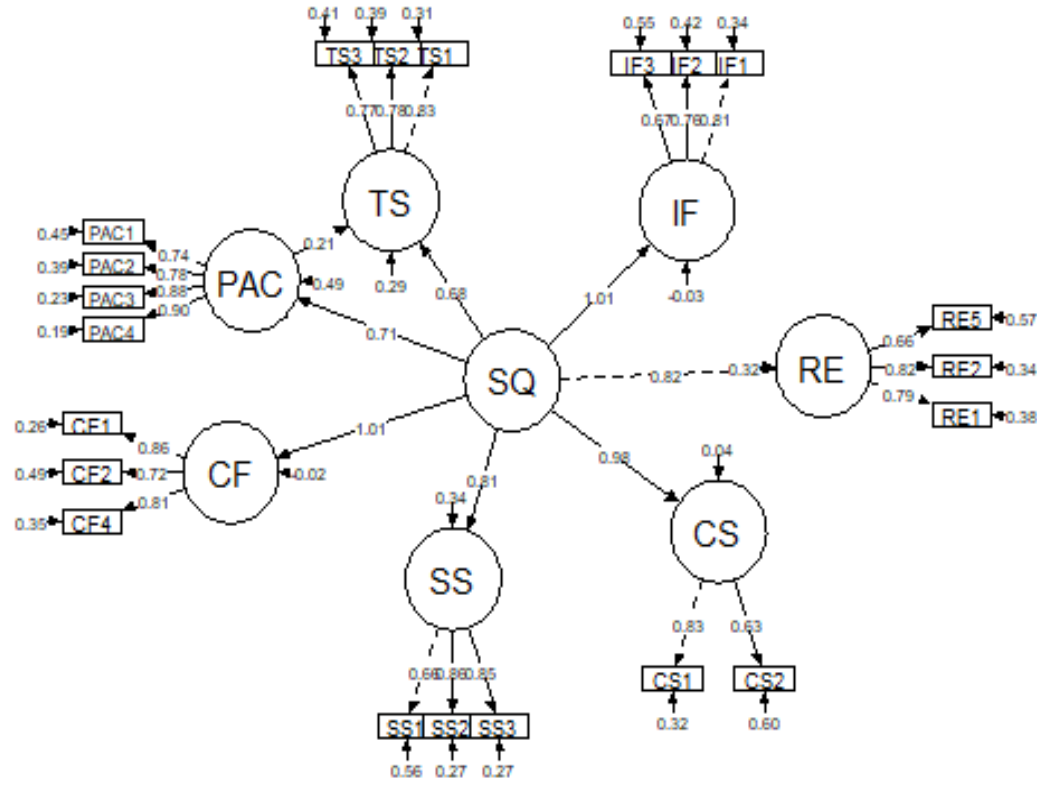

Figure 4. Structural model
The data used in this study are normally distributed after removing the outlier data from the Mahalanobis test for five iterations. Thus, the final data used in this study is 161 data out of the 264 original data. The measurement scale used in this study is the 7 point Likert Scale. This scale appears to be the optimum option for a questionnaire in usability, satisfaction survey, or evaluation (Finstad, 2010). According to Hair et al. (2009), standardized loading estimates should be at least 0.5 and ideally at least 0.7 . Therefore, the second-order model was used to be combined with the full model. There is no standardized loading less than 0.5 , so the analysis can be continued. The results of the confirmatory analysis are compared to the Goodness-of-Fit criteria, which indicates how effectively the proposed model creates the observed covariance matrix between items. It compares theory to reality, and the closer the values are to one other, the better.

It may be deduced from the test results that the model met the Goodness of Fit standards even though it has a high ChiSquare value. Since the Chi-Square value may be sensitive to the number of samples, as a result, if the Chi-Square value is significant, it is recommended to neglect it and focus on other Goodness of Fit criteria. Model called fit when the value of Goodness-of-Fit criteria has been fulfilled. Below the list of GoF criteria that must be fulfilled (Kassim et al., 2013; Kawesittisankhun and Pongpeng, 2019). Therefore, this model is fit based on the Goodness-of-Fit recommended criteria. The model modification passed for 17 iterations, i.e., 8 in second-order and 9 in the full model. Figure 4 describes how the structural model was modified based on the Confirmatory Factor Analysis (CFA) method to provide an acceptable model (fit).

Table 3. Evaluation of Goodness of Fit (GoF)

\begin{tabular}{|l|l|l|l|}
\hline Criteria & Recommended & Observed & Results \\
\hline $\begin{array}{l}\text { Chi-square }\left(\chi^{2}\right) \text { of } \\
\text { estimated model }\end{array}$ & & $\begin{array}{l}207.124, \\
\text { DF }=164\end{array}$ & \\
\hline Significance level & $\mathrm{p}<0.05$ & 0.013 & fit \\
\hline Normed Chi-square & $3.0>\left(\chi^{2}\right) / D F>1.0$ & 1.26 & fit \\
\hline RMSEA & $<0.08$ & 0.040 & fit \\
\hline GFI & $>0.9$ & 0.893 & marginal fit \\
\hline AGFI & $>0.9$ & 0.850 & marginal fit \\
\hline TLI & $>0.9$ & 0.977 & fit \\
\hline CFI & $>0.9$ & 0.982 & fit \\
\hline IFI & $>0.9$ & 0.982 & fit \\
\hline
\end{tabular}

Table 4. Regression and defined parameters

\begin{tabular}{|l|l|l|l|l|l|l|l|}
\hline Regressions & & & & & & & \\
\hline & & $\begin{array}{l}\text { Estimat } \\
\text { e }\end{array}$ & $\begin{array}{l}\text { Std.Er } \\
\text { r }\end{array}$ & $\begin{array}{l}\text { Z- } \\
\text { value }\end{array}$ & $\mathrm{P}(>\mid \mathrm{z})$ & Std.lv & Std.all \\
\hline PAC $\sim$ & & & & & & & \\
\hline & SQ (c) & 0.562 & 0.144 & 3.893 & 0.000 & 0.706 & 0.706 \\
\hline TS & & & & & & & \\
\hline & SQ (a) & 0.851 & 0.148 & 5.730 & 0.000 & 0.679 & 0.679 \\
\hline & PAC (b) & 0.312 & 0.154 & 2.023 & 0.043 & 0.198 & 0.198 \\
\hline $\begin{array}{l}\text { Defined } \\
\text { Parameters }\end{array}$ & & & & & & & \\
\hline medvar & & 0.175 & 0.082 & 2.138 & 0.033 & 0.140 & 0.140 \\
\hline
\end{tabular}

In this research, there is a mediating variable which is the Perceived Accessibility Scale. It means perceived accessibility transmits the effect of service quality to increase satisfaction with travel. According to results in $\mathrm{R}$ studio, for every $\mathrm{c}=0.706$ unit increase in association between service quality and perceived accessibility, there was "medvar" $=$ 0.140 increase in satisfaction with travel as shown in Table 4. SEM analysis provides the result of hypotheses testing. A standardized solution carried out the result in $\mathrm{R}$ studio. First, the null hypotheses are accepted and reject the alternative hypotheses with the p-value $>0.05$ and $\mathrm{z}$-score $<1.96$. Then the null hypotheses are rejected and accept the alternative hypotheses with the $\mathrm{p}$-value $<0.05$ and z-score $>1.96$. Table 5 provides two operations, regression and pointed-out. The " $=\sim$ " is used to pointed-out the variable of the construct. In this case, service quality was built by five dimensions. The p-value of each variable with service quality is significant, and the z-score also has a great score. It means the subvariables of service quality represent the service quality variable. Table 6 is the result of hypothesis checking.

Table 5. Standardized solution

\begin{tabular}{|c|c|c|c|c|c|c|c|c|}
\hline lhs & op & rhs & est.std & se & z & pvalue & ci.lower & ci.upper \\
\hline PAC & $\sim$ & SQ & 0.706 & 0.052 & 13.651 & 0.000 & 0.605 & 0.808 \\
\hline TS & $\sim$ & SQ & 0.679 & 0.080 & 8.526 & 0.000 & 0.523 & 0.835 \\
\hline TS & $\sim$ & PAC & 0.198 & 0.088 & 2.261 & 0.024 & 0.026 & 0.370 \\
\hline SQ & $=\sim$ & RE & 0.933 & 0.048 & 19.569 & 0.000 & 0.840 & 1.026 \\
\hline SQ & $=\sim$ & SS & 0.890 & 0.038 & 23.268 & 0.000 & 0.815 & 0.965 \\
\hline SQ & $=\sim$ & IF & 1.011 & 0.017 & 58.606 & 0.000 & 0.977 & 1.044 \\
\hline SQ & $=\sim$ & CF & 1.010 & 0.014 & 73.119 & 0.000 & 0.983 & 1.037 \\
\hline SQ & $=\sim ~$ & CS & 0.874 & 0.152 & 5.747 & 0.000 & 0.576 & $1 / 172$ \\
\hline
\end{tabular}

Table 6. Hypothesis testing result

\begin{tabular}{|c|c|c|}
\hline Hypothesis & Path & Conclusion \\
\hline H1 & $\begin{array}{c}\text { Service Quality } \rightarrow \text { Satisfaction with } \\
\text { Travel }\end{array}$ & Accepted \\
\hline H2 & $\begin{array}{c}\text { Service Quality } \rightarrow \text { Perceived } \\
\text { Accessibility Scale }\end{array}$ & Accepted \\
\hline H3 & $\begin{array}{c}\text { Perceived Accessibility Scale } \rightarrow \\
\text { Satisfaction with Travel }\end{array}$ & Accepted \\
\hline
\end{tabular}


Based on Table 5, the p-value and z-score between Service Quality (SQ) and Satisfaction with Travel (TS) are 0.000 and 8.526. According to the rule of thumb, this alternative hypothesis is accepted. The relationship has the second strongest relationship (0.679). Based on Table 5, the p-value and z-score between Service Quality (SQ) and Perceived Accessibility Scale (PAC) are 0.000 and 13.651. According to the rule of thumb, this alternative hypothesis is accepted. The relationship has the strongest relationship (0.706). Based on Table 4, the p-value and z-score between Perceived Accessibility Scale (PAC) and Satisfaction with Travel (TS) are 0.024 and 2.261 but have the weakest relationship (0.198). The p-value is less than 0.05 , and the $\mathrm{z}$-score is greater than 1.96 . In this case, accept the alternative hypothesis.

\section{Thematic Analysis Result}

The thematic analysis uses RQDA ( $R$ Qualitative Data Analysis) as a software application to evaluate the qualitative data. In order to perform the RQDA, some packages should be installed in R studio, showing the RQDA GUI. After the installment, qualitative data can be transferred to RQDA using the txt file type. The qualitative data used in this research is the data that has a negative word such as critics. The codes were created and assigned to each of the sentences. The codes used were the service quality indicators because the questionnaire asks the respondent's opinion about service quality in MRT Jakarta during the pandemic of COVID-19. The codes also turned to be negative values. Visualization of the data should be generated in Rstudio, not in RQDA GUI (Graphical User Interface).The data visualization shows the frequency of the code of review from passengers of MRT Jakarta gathered by questionnaire. The most frequent indicator that given by respondents is SS1 about the presence of a security guard (Figure 5).

\section{DISCUSSION}

The following discussion will examine the findings of a study on the impact of service quality on perceived accessibility and satisfaction with travel in MRT Jakarta.

\section{The Effect of Service Quality on Satisfaction with Travel}

The result of testing the H1 hypothesis indicates that service quality significantly affects satisfaction with travel. This result aligns with the research done by Shah et al. (2020), Soltanpour et al. (2020), Sze-Siong and Aksan (2018), and Monmousseau et al., 2020 that showed service quality significantly affects travel satisfaction. Therefore, service provided by the transport system should fulfil travel needs to reach satisfaction with travel. However, the object is different from the previous studies. In this study, the object is MRT Jakarta as the public transport whereas the other is airplane and urban rail. Therefore, it means the service quality in public transportation affects satisfaction with travel.

\section{The Effect of Service Quality on Perceived Accessibility}

Testing the $\mathrm{H} 2$ hypothesis indicates that service quality has a significant effect on perceiving accessibility scale. It aligns with the research done by Lättman et al. (2016b) and Friman et al. (2020) which showed that service quality appears to be positively related and important to perceived accessibility. The service quality dimensions used in this research are reliability, safety security, information, comfort, and cost, the same as the previous research. This may suggest that 161 respondents feel the service quality with these dimensions is related and directly affects perceived accessibility in the pandemic of COVID-19.

\section{The Effect of Perceived Accessibility Scale on Satisfaction with Travel}

Testing the $\mathrm{H} 3$ hypothesis indicates that perceived accessibility as a mediating variable significantly affects satisfaction with travel. In the previous study, Lättman et al. (2019) and Inturri et al. (2021) showed that perceived accessibility is related to satisfaction with travel. The perceived accessibility captures the individual's experience related to social consequences towards the objective transportation environment. When the users perceive more accessible transportation, they feel it is easier to live the life they want. In the previous study, they used moderation for the age group. It founds that perceived accessibility is important for each segmentation of age for their satisfaction with travel.

Based on Figure 5, the qualitative data gathered from the reviews given from passengers to MRT Jakarta using the thematic analysis with the RQDA software. The data only used the negative value to provide further recommendations to service quality in MRT Jakarta. The most frequent code frequency from respondents' review of MRT Jakarta is SS1 about the presence of security guards, followed by SS2 about the risk of interference from other passengers. The SS2 indicator talked about the presence of the guard and the behaviour presence of the guard. Many respondents said about the misbehaved of the guard in treating the passengers. In comparison, the SS1 talked about the lack of other passengers obeying health protocols, so they do not feel safe and secure. Several design strategies can be recommended based on the result obtained in this study. Policy measures should be formulated to improve the satisfaction level of the MRT Jakarta's passengers. Various improvements are suggested in the following points related to service attributes such as:

a. Increase the security guard or staff officer for controlling health protocols at the station or inside the train. 
b. The security guard or staff officers of MRT Jakarta should be friendly behavior towards passengers and still be assertive.

c. Fares and schedules information should be consistent.

d. The train should run on schedule, not too early or too late.

\section{CONCLUSION AND FUTURE RESEARCH}

Structural equation model is a versatile method for evaluating and investigating how variables relate to one another. It involves measurement and structural models (Bauldry, 2015; Hair et al., 2009; Kassim et al., 2013). Based on the study results, the satisfaction with travel would increase if perceived accessibility is increasing by service quality. Based on the study results, the satisfaction with travel would increase if perceived accessibility is increasing by service quality.

The increase of perceived accessibility will make the users more accessible and easier to live their lives, leading to satisfaction with travel. Perceived accessibility as a mediating variable mediated service quality and satisfaction with travel. It means when the service quality gives effect to perceived accessibility, there is also an effect from perceived accessibility that affects satisfaction with travel. Thematic analysis is applied to examine classifications and display themes related to the data. The qualitative data processed with thematic analysis showed the most frequency quality concerned in MRT Jakarta is SS1 (Presence of Guard) and SS2 (Risk of Interference with Other Passengers).

This research can be used to determine, evaluate, and develop the service quality for the perceived accessibility and passenger's satisfaction in MRT Jakarta, especially during and after the COVID-19 pandemic. Also, it can be used for the following research and as a comparison for another research. In other words, variables and indicators can be added for more complex research. Especially the sub-dimensions of service quality to provide a comprehensive picture of which quality factors are crucial for satisfaction with travel and perceived accessibility. The COVID-19 variable may be used as moderating variable for the relationship between service quality, perceived accessibility, and travel satisfaction. More samples can also be added for future research for a better SEM analysis. More observations would give a more accurate fit for the model. The number of samples between the choice and captive users should be balanced.

\section{REFERENCES}

Bartlett, J.E., Kotrlik, J.W., \& Higgins, C.C. (2001). Organizational research: Determining appropriate sample size in survey research. Information Technology, Learning, and Performance Journal, 19(1), 43-50. https://doi.org/10.1007/BF00471876

Bauldry, S. (2015). Structural Equation Modeling. International Encyclopedia of the Social \& Behavioral Sciences: Second Edition, 615-620. https://doi.org/10.1016/B978-0-08-097086-8.44055-9

Chauhan, V., Gupta, A., \& Parida, M. (2021). Demystifying service quality of Multimodal Transportation Hub (MMTH) through measuring users' satisfaction of public transport. Transport Policy, 102, 47-60. https://doi.org/10.1016/i.tranpol.2021.01.004

Cheng, Y.H., \& Chen, S.Y. (2015). Perceived accessibility, mobility, and connectivity of public transportation systems. Transportation Research Part A: Policy and Practice, 77, 386-403. https://doi.org/10.1016/j.tra.2015.05.003

Chomeya, R. (2010). Quality of psychology test between likert scale 5 and 6 points. Journal of Social Sciences, 6(3), $399-403$. https://doi.org/10.3844/jssp.2010.399.403

Davvetas, V., Diamantopoulos, A., Zaefarian, G., \& Sichtmann, C. (2020). Ten basic questions about structural equations model ing you should know the answers to - But perhaps you don't. Industrial Marketing Management, 90(June), 252-263. https://doi. org/10.1016/j.indmarman.2020.07.016

De Oña, R., MacHado, J.L., \& De Oña, J. (2015). Perceived service quality, customer satisfaction, and behavioral intentions structural equation model for the Metro of Seville, Spain. Transportation Research Record, 2538(January), 76-85. https://doi.org/10.3141/2538-09

Dong, X., Ben-Akiva, M.E., Bowman, J.L., \& Walker, J.L. (2006). Moving from trip-based to activity-based measures of accessibility. Transportation Research Part A: Policy and Practice, 40(2), 163-180. https://doi.org/10.1016/j.tra.2005.05.002

Finstad, K. (2010). Response interpolation and scale sensitivity: Evidence against 5-point scales. Journal of Usability Studies, 5(3), 104-110.

Friman, M., Lättman, K., \& Olsson, L.E. (2020). Public transport quality, safety, and perceived accessibility. Sustainability (Switzerland), 12(9). https://doi.org/10.3390/SU12093563

Hair, J.F., Black, W.C., Babin, B.J., \& Anderson, R.E. (2009). Multivariate Data Analysis. In Pearson New International Edition : Seventh Edition (Seventh). Pearson Education Limited. https://doi.org/10.4324/9781351269360

Haron, S., Nasir, M.S.B., \& Mohamad, S.S. (2016). Rail transport service performance indicators in Klang Valley. AIP Conference Proceedings, 1774(October 2016). https://doi.org/10.1063/1.4965078

Haron, S., Noor, S.M., Farhan, A., \& Sadullah, M. (2015). New dimension of bus service quality performance measure. Proceedings of International Conference on Advances in Computing. 174 AISC(October). https://doi.org/10.1007/978-81-322-0740-5

Henderson, R. (2013). Service quality: A critical literature review. Global Journal of Management and Business Research Marketing, 13(8), 1-6. https://journalofbusiness.org/index.php/GJMBR/article/view/1106

Heriyanto, H. (2018). Thematic Analysis sebagai metode menganalisa data untuk penelitian kualitatif. Anuva, 2(3), 317. https://doi. org/10.14710/anuva.2.3.317-324

Hox, J., \& Bechger, T.M. (2015). An introduction to structural equation modeling. Family Science Review, 11, 354-373. https://doi. org/10.3233/978-1-61499-538-8-3

Hussein, A.S., \& Hapsari, R. (2014). How quality, value and satisfaction create passenger loyalty: An empirical study on Indonesia bus rapid transit passenger. The International Journal of Accounting and Business Society, 22(2), 95-115.

Hsu, C.L., \& Liao, Y.C. (2019). Bridging user perception and stickiness in business microblog contexts: A moderated mediation model. Future Internet, 11(6), 1-16. https://doi.org/10.3390/FI11060134

Inturri, G., Giuffrida, N., Le Pira, M., Fazio, M., \& Ignaccolo, M. (2021). Linking public transport user satisfaction with service accessibility for sustainable mobility planning. ISPRS International Journal of Geo-Information, 10(4), 235. https://doi.org/10.3390/ijgi10040235

Kassim, N.L.A., Daud, N.M., \& Daud, N.S.M. (2013). Interaction between writing apprehension , motivation , attitude and writing performance : A Structural Equation Modeling approach interaction between writing apprehension, motivation , and attitude. World Applied Sciences Journal 21, 102-108. https://doi.org/10.5829/idosi.wasj.2013.21.slt1.2143

Kawesittisankhun, K., \& Pongpeng, J. (2019). Relationships of construction project manager , engineer , and foreman skills. International Conference on Engineering, Applied Sciences and Technology. https://doi.org/10.1088/1757-899X/639/1/012027

Khairulbahri, M. (2021). Lessons learned from three Southeast Asian countries during the COVID-19 pandemic. Journal of Policy Modeling. https://doi.org/10.1016/j.jpolmod.2021.09.002 
Kim, K., Francis, O., \& Yamashita, E. (2018). Learning to build resilience into transportation systems. Transportation Research Record, 2672(1), 30-42. https://doi.org/10.1177/0361198118786622

Koufteros, X., Babbar, S., \& Kaighobadi, M. (2009). A paradigm for examining second-order factor models employing structural equation modeling. International Journal of Production Economics, 120(2), 633-652. https://doi.org/10.1016/i.ipe.2009.04.010

Lai, W.T., \& Chen, C.F. (2011). Behavioral intentions of public transit passengers-The roles of service quality, perceived value, satisfaction and involvement. Transport policy, 18(2), 318-325. https://doi.org/10.1016/j.tranpol.2010.09.003

Laili, M. \& Otok, B.W. (2014). Second-Order Confirmatory Factor Analysis pada Kemiskinan di Kabupaten Jombang. Jurnal Sains Dan Seni ITS, 3(2), 278-283. https://doi.org/10.12962/J23373520.V3I2.8161

Lättman, K., Friman, M., \& Olsson, L.E. (2016a). Perceived accessibility of public transport as a potential indicator of social inclusion. Social Inclusion, 4(3), 36-45. https://doi.org/10.17645/si.v4i3.481

Lättman, K., Olsson, L.E., \& Friman, M. (2016b). Development and test of the Perceived Accessibility Scale (PAC) in public transport. Journal of Transport Geography, 54, 257-263. https://doi.org/10.1016/j.jtrangeo.2016.06.015

Lättman, K., Olsson, L.E., Friman, M., \& Fujii, S. (2019). Perceived accessibility, satisfaction with daily travel, and life satisfaction among the elderly. International Journal of Environmental Research and Public Health, 16(22). https://doi.org/10.3390/ijerph16224498

Lewis, J.R. (1993). Multipoint scales: Mean and median differences and observed significance levels. International Journal of HumanComputer Interaction, 5(4), 383-392. https://doi.org/10.1080/10447319309526075

Mandhani, J., Nayak, J.K., \& Parida, M. (2020). Interrelationships among service quality factors of Metro Rail Transit System: An integrated Bayesian networks and PLS-SEM approach. Transportation Research Part A: Policy and Practice, 140(March), 320-336. https://doi.org/10.1016/i.tra.2020.08.014

Mellado, B.H., Brandão, C., Pilger, T.L., \& dos Reis, F.J.C. (2020). Using Rqda in Qualitative data analysis: A tool for researching chronic pelvic pain using Thematic Analysis. New Trends in Qualitative Research, 1, 153-170. https://doi.org/10.36367/ntqr.1.2020.153-170

Márquez, L., Poveda, J.C., \& Vega, L.A. (2019). Factors affecting personal autonomy and perceived accessibility of people with mobility impairments in an urban transportation choice context. Journal of Transport \& Health, 14, 100583. https://doi.org/10.1016/i.jth.2019.100583

Monmousseau, P., Marzuoli, A., Feron, E., \& Delahave, D. (2020). Impact of Covid-19 on passengers and airlines from passenger measurements: Managing customer satisfaction while putting the US Air Transportation System to sleep. Transportation Research Interdisciplinary Perspectives, 7, 100179. https://doi.org/10.1016/j.trip.2020.100179

Mukaka, M.M. (2012). Statistics corner: A guide to appropriate use of correlation coefficient in medical research. Malawi Medical Journal, 24(3), 69-71.

Nguyen Van, P., Nguyen, H.T., \& Le, T.B. (2018). A Study on Factors Affecting on Customer Intention to Use the Express Bus. VNU Journal of Science: Economics and Business, 34(5E), 81-92. https://doi.org/10.25073/2588-1108/vnueab.4167

Parasuraman, A., Berry, L.L., \& Zeithaml, V.A. (1988). SERVQUAL: A multiple-item scale for measuring consumer perceptions of service quality. Journal of Retailing, 64(1), 12-40. https://doi.org/10.1016/0022-4359(94)90033-7

Parasuraman, A., Zeithaml, V.A., \& Berry, L.L. (1985). A conceptual model service its quality and implications for future research. Research Paper, 49(4), 41-50. http://dx.doi.org/10.2307/1251430

Purnomo, A.H., \& Mufhidin, A. (2020). Analysis of customer satisfaction on quality of Jakarta corridor MRT (mass rapid transit) service 1 (Lebak bulus Station - Bundaran HI). International Journal of Integrated Education, Engineering and Business, 3(2), 71-80. https://doi.org/10.29138/ijieeb.v3i2.1168

Redman, L., Friman, M., Gärling, T., \& Hartig, T. (2013). Quality attributes of public transport that attract car users: A re search review. Transport Policy, 25, 119-127. https://doi.org/10.1016/j.tranpol.2012.11.005

Salleh, I.S., Ali, N.S.M., Mohd-Yusof, K., \& Jamaluddin, H. (2017). Analyzing qualitative data systematically using thematic analysis for deodorizer troubleshooting in palm oil refining. Chemical Engineering Transactions, 56(1998), 1315-1320. https://doi.org/ 10.3303/CET1756220

Santosa, W., \& Basuki, T. (2003). Jakarta mass rapid transit project: An economic review. Proceedings - Conference of the Australian Road Research Board, 21(1), 2235-2254.

Shah, F.T., Syed, Z., Imam, A., \& Raza, A. (2020). The impact of airline service quality on passengers' behavioral intentions using passenger satisfaction as a mediator. Journal of Air Transport Management, 85, 101815. https://doi.org/10.1016/i.jairtraman.2020.101815

Shaw, R., Kim, Y.K., \& Hua, J. (2020). Governance, technology and citizen behavior in pandemic: Lessons from COVID-19 in East Asia. Progress in Disaster Science, 6, 100090. https://doi.org/10.1016/j.pdisas.2020.100090

Showkat, N., \& Parveen, H. (2017). Non-probability and probability sampling. In Communications Research (Issue August).

Soltanpour, A., Mesbah, M., \& Habibian, M. (2020). Customer satisfaction in urban rail: a study on transferability of structural equation models. Public Transport, 12(1), 123-146. https://doi.org/10.1007/s12469-019-00223-y

Sreejesh, S., Mohapatra, S., \& Anusree, M.R. (2014). Business Research Methods. In Business Research Methods (Issue November 2015). Springer US. https://doi.org/10.22573/spg.020.bk/s/026

Steinwender, L., Holy, D., Burkhard, J., \& Uçkay, I. (2021). Daily use of public transportation and incidence of symptomatic COVID-19 among healthcare workers during the peak of a pandemic wave in Zurich, Switzerland. American Journal of Infection Control. https://doi.org/10.1016/i.aiic.2021.10.022

Sukwadi, R. (2015a). Utilizing Customer Experience Management framework to create a delightful service experience. International Journal of Industrial Eneineering and Management, 6(1), 29-42

Sukwadi, R. (2015b). The implementation of quality management practices in Indonesian SMEs. International Journal of Trade and Global Markets, 8(3), 207-222. https://doi.org/10.1504/IJTGM.2015.071604

Sukwadi,R., Yang, C.C., \& Liu Fan, L. (2012). Capturing customer value creation based on service experience - a case study on News Café, Journal of the Chinese Institute of Industrial Engineers, 29(6), 383-399. https://doi.org/10.1080/10170669.2012.713033

Sze-Siong, C., \& Aksan, A. (2018). Users' satisfaction with mass rapid transit and the effect of different genders and trip purposes. International Journal of Academic Research in Business and Social Sciences, 8(15), 131-145. https://doi.org/10.6007/IJARBSS/v8-i15/5097

van Empel, G., Mulyanto, J., \& Wiratama, B.S. (2020). Undertesting of COVID-19 in Indonesia: what has gone wrong? Journal of Global Health, 10(2),020306. https://doi.org/ 10.7189/jogh.10.020306

Woodruff, R.B. (1997). Customer value: The next source for competitive advantage. Journal of the Academy of Marketing Science, 25(2), 139-153. https://doi.org/10.1007/BF02894350

Yao, Y., Geara, T.G., \& Shi, W. (2021). Impact of COVID-19 on city-scale transportation and safety: An early experience from detroit. Smart Health, 22, 100218. https://doi.org/10.1016/j.smhl.2021.100218

Yuniarti, A., \& Aditya, T. (2020). Service quality terhadap kepuasan masyarakat mass rapid transit (MRT) DKI Jakarta di stasiun Lebak Bulus pada masa pandemik Covid-19. Jurnal Ilmiah Ilmu Administrasi, 10(2), 55-69. https://doi.org/10.33592/jiia.v10i2.840

Zhao, J., Webb, V., \& Shah, P. (2014). Customer loyalty differences between captive and choice transit riders. Transportation Research Record, 2415, 80-88. https://doi.org/10.3141/2415-09 